\title{
Corruption in Media Construction: Superstructure Analysis of Corruption News Texts in Indonesian National Private Television
}

\author{
Hari Bakti Mardikantoro ${ }^{1}$ Haryadi $^{2}$ \\ ${ }^{1,2}$ Faculty of Language and Arts, Universitas Negeri Semarang \\ ${ }^{1}$ Corresponding email: haribaktim@mail.unnes.ac.id
}

\begin{abstract}
One of the topics that always appear and attract attention is the news of corruption on television. This topic alwaysappears to be headline news. This happens because corruption almost always occurs in Indonesia even it has been entrenched. Corruption has become the lifestyle of our officials. This research is aimed at analyzing textual practice in corruption news texts in Indonesian national private television. The research is descriptive qualitative study by employing critical discourse analysis theory proposed by Van Dijk. The method of data collection employed simak method by using the advanced rekam and catat technique. The analysis used in this study is the discourse analysis technique proposed by Teun A van Dick. The results showed that the textual dimension of superstructure aspects of corruption news text in television tends to stand up for refusal and critics of the corruption. The news reporters from Metro $T V$ tend to use informal style, euphemistic expression, and passive voice. However, those from NET use simple diction, active sentence, and metaphor. From those findings, generally, the news reporters tend to marginalize the corruptors and give a positive image to the law enforcement.
\end{abstract}

Keywords: critical discourse analysis, Teun A. van Dijk, corruption news text

\section{Introduction}

Language has the main use as a communication tool. Communicating by using language can be done in oral and written form. One of the written forms which are commonly used is press language. Within the context of the language used in the press, languageis used as the information conveyer. It is in line with what is proposed by Brown and Yule (1996:2) and Leech (1997:47) which stated that although the language has various communicative functions, language as the information conveyer is the most prominent.

Press media is often referredto as the fourth estate in socio-economic and political life. This is mainly due to a perception of the role that media can play about the development of the socio-economic and political life of the community. As a tool for conveying news, judgments or general descriptions of many things, the press media has the ability to act as an institution that can shape public opinion among others because the media can also develop into a pressure group on an idea and even an interest or image represented to be placed in a more empirical context of life (Sobur, 2002: 30).

One of the topics that always appear and attract attention is the news of corruption on television. This topic alwaysappears to be headline news (Mardikantoro, 2014: 216). This happens because corruption almost always occurs in Indonesia even it has been entrenched. Corruption has become the lifestyle of our officials. The problem of corruption tends to be endless. From day to day, it always happens. Thisis evidenced by the Indonesian Indicator (I2) indicating the total number of corruption reports which reached 152,346 out of a total of $1,872,234$ reports from January 1st to December 9th, 2013. This means that corruption cases account for 8.14 percent of all news in Indonesia apart from infotainment. Corruption news in 2013 which is as many as 12,656 per month increased compared to those in 2012 which reached 107,936 news or about 8995 news per month. Researcher I2 noted the frequency of corruption is high enough than other themes such as poverty which reached 2,724 news per month (Ridwan, 2013).

In this study, the texts of corruption reports on Indonesian national private television were analyzed with critical discourse analysis. Critical discourse analysis is an attempt or process to describe a text (social reality) that is studied by a person or a dominant group whose tendency has a particular purpose to obtain what is desired (Jorgensen and Phillips, 2007). This means that in a context, there must be an awareness of the importance (Darma, 2009: 49). In addition, the critical approach places discourse as power (Asher and Simpson, 1994: 940; Fairclough, 1995; Dijk, 1988). Renkema (2004: 282) views discourse as a reflection of a 
power relation within a society. The critical approach understands discourse as a form of social practice (Fairclough and Wodak, 1997; Wodak and Meyer, 2006). In social practice, a person always has a discourse purpose, including a goal to exercise power. When that happens, discourse practices will display the ideological effect of producing and reproducing unequal power relationships between the male and female social classes or the majority and minority groups (Subagyo 2010: 177).

The critical discourse analysis of the van Dijk model views how the produced text works. Van Dijk (in Eriyanto, 2011: 225) describes three dimensions or buildings used in discourse analysis namely the facet of text, social cognition, and social context. These three dimensions of discourse are the parts incorporated into the unity of analysis.

The text dimension in critical discourse analysis of van Dijk model is divided into three structures namely macro structure, superstructure, and micro structure (Eriyanto , 2011: 226, Dijk, 1988: 17-94). This section only discussed the dimensions of corruption news text reviewed from the superstructure according to the Van Dijk model. Superstructure is the structure of discourse related to the framework of a text, how the parts of the text are composed into the news as a whole.

\section{Methods}

The problem investigation in this research uses two approaches, namely empirical sociological approach and critical approach. The empirical sociological approach understands discourse as a speech event that is bound by the context of the situation (Asher and Simpson 1994: 940). This research also used a critical approach. This approach places discourse as power (Asher and Simpson 1994; Fairclough, 1995; Dijk, 1988) or views discourse as a reflection of relationships within society.

The data in this research were collected by using the simak method (Sudaryanto 2015: 203). The method was followed by the use of rekam and catat techniques. The data analysis in this research used critical discourse analysis model proposed by van Dijk (Wodak and Meyer, 2006). Van Dijk divides discourse analysis into three dimensions, namely the dimensions of the text, the dimensions of social cognition, and the dimensions of social context/practice (Dijk, 1980; Dijk, 1988). A text consists of three structures is macro structures, superstructures, and micro structure.

\section{Results and discussion}

In the superstructure, the observed thing is the schematic of the whole series of topics or the global content of the news or the news flow from the introduction to the end. This superstructure organizes topics by arranging sentences or news units based on the order or desired hierarchy. Dijk (1988: 52) formulates a number of categories of news schemes or sections that construct a news scheme namely (1) a summary, commonly characterized by two elements: title and lead, and (2) story, ie the content of the news as a whole from the introduction to the end.

The first news analysis is concerned withthe case of bribery quotas of sugar imports that ensnare Irman Gusman. According to the news on Metro TV, the newsis constructed under the title "Bribery Case of Irman Gusman" (October 4, 2016). The title of the news is only utilizing the subject phrase so that it looks focused emphasize on the bribery case committed by Irman Gusman. The phrase "Bribery Case of Irman Gusman" led to the understanding of the community that the mastermind of the bribery case is Irman Gusman. After the title, the news is followed by the leads as follows.

(1) Team 10 or team formed by DPD to review cases related to Irman Gusman again held hearings. This time Team 10 hears the views of the President Director of Bulog, Djarot Kusumayakti. (Bribery Case of Irman Gusman, Metro TV, October 4, 2016)

The lead is an introduction or summary of what to say before entering the complete news content. The lead or terrace of the news contains the intention that the Irman Gusman case is so important that the DPD formed Team 10 to examine specifically the bribery case of the sugar import quota.

The main event in the Metro TV news entitled "Bribery Case of Irman Gusman" is the assessment of the DPD on Bulog bribery case that ensnared Irman Gusman. The assessment was carried out by listening to the opinions and views of the Bulog Director, Djarot Kusumayakti who had contacted Irman Gusman about the telephone. Djarot confirmed that he got a call from Irman Gusman regarding the 
state of sugar prices in West Sumatra and Irman recommended Memi as a sugar distributor in this case. After reporters reported directly on the course of the hearing with Team 10, journalists inserted Djarot's footage to corroborate the broadcast news report, and the news ended with the next agenda plan. The background of the hearing held by the Team 10 was because the suspect, Irman Gusman is the DPD chairman, so it needs to be investigated in depth. Therefore, the agenda of the hearings is interesting to be reported because it involves important figures who commit criminal acts of bribery.

Unlike news schemes or flows in NET, in the same case, bribery cases of imported sugar quotas, NET reporters construct their brief and concise reports. The news titled "Irman Gusman was re-investigated by Corruption Eradication Commission" which aired on October 4, 2016, was constructed by putting the main idea at the beginning of the news or leads explaining the inspection of Irman Gusman by the Corruption Eradication Commission, as in the following fragment.

(2) Tuesday afternoon, former Chairman of the Regional Representative Council, Irman Gusman was again investigated by the Corruption Eradication Commission. Suspected cases of alleged bribery recommendation of sugar import quota are claimed not to know about bribe money received. (Irman Gusman was Reinvestigated by Corruption Eradication Commission, NET, October 4, 2016)

In the first paragraph, the reporter indicated Irman Gusman's denial of the bribe he received. It is reinforced by an excerpt from Irman Gusman's speech. However, in the next paragraph, the reporter raised a statement contrary to the first paragraph by showing a statement from Djarot Kusumayakti about Irman Gusman's phone call to him. The news ended with an explanation of the chronology of Irman Gusman's arrest and the linkage of the bribery case. Viewed schematically, the above news shows the results of Irman Gusman's investigation by the Corruption Eradication Commission. The statement provides a statement of contradiction with a marked statement of conflicting figures. At the end of the news, the reporter concluded the chronology of Irman Gusman's arrest with the aim that the public can conclude its preference from the news.

Viewed schematically, the above news shows the truth of the bribery case by holding a hearing. The news has a sequential scheme by presenting facts that support the main idea.

Analysis of the second news is about the case of illegal levies in the Ministry of Transportation. In the news on Metro TV, the newswas constructed under the title "Eradicate Illegal Levies" (October 12, 2016). The headline utilizes the verb phrase and adjective phrase so that the focus of the news emphasizes the process of eradication action. From the title of the news, reporters present leads or a brief overview of news content at the beginning of the news, as follows.

(3) The six unexpected cases of illegal levy from the results of hand operation last night were brought to Polda Metro Jaya. (Bribery Case of Irman Gusman, Metro TV, October 4, 2016)

The main idea lies in the second paragraph regarding the alleged illegal investigation in the Ministry of Transportation. The reporting scheme begins with leads explaining that it was allegedly taken to the Jakarta Police. Then the reporter explains who the unlawful perpetrators of illegal charges are at the end of the second paragraph. In the next paragraph/section of the news, the reporter explained the evidence found and the reason for the illegal levies. At the end of the story, the reporter informed about the suspect's determination plan. The main event in Metro TV news entitled "Bribery Case of Irman Gusman" is the assessment of the DPD on the Bulog bribery case that ensnared Irman.

Viewed schematically, the above news shows the general outline of the illegal levy case that occurred in Ministry of Transportation. The news has a scheme that is less detailed and does not generate strong explanatory data, such as the speech of the figures associated with the case.

While in the same case, the NET reporters constructed the news on illegal levies in Ministry of Transportation entitled "Six People were Investigated by Polda Metro Jaya Related to Illegal Levy" on October 12, 2016.

(4) Six unpredictable illegal collectors in the Directorate of Sea Transportation, on Tuesday night, were taken to Polda Metro 
Jaya for questioning. (Six People were Investigated by Polda Metro Jaya Related to Illegal Levy, NET, October 12, 2016)

In the news, the main idea of news is in the first paragraph that shows the investigation of the six actors of levy in Dirhubla. Then it is followed by an explanatory sentence about who the perpetrators of illegal fees were and what evidences were found. Thisis reinforced by the statement Kombes Pol Awi Setiyono about the evidence. In the next paragraph, furthermore, the reporter explained the known chronology of the citizens' report on some agencies that conduct bribery. Then the reporter stated the trace of the practice of bribery and extortion in the Ministry of Transportation. However, the party of Ministry of Transportation claimed that they do not have the authority to arrest. This is reinforced by the speech of Dewa Made Sastrawan. At the end of the news, the reporter gave his opinion on the supervision at the Ministry of Transportation and the deadline the police had to determine the status of the suspect.

Viewed schematically, the news above shows the news in detail and special way. It is seen from the selection of titles that have led to the suspect of levy and news constructed from the main idea followed by a reliable explanatory sentence, for example, footage of figures associated with the case. Additionally, at the end of the reporter's report, he also informs the next plan after the investigation of the determination of the suspect.

The third news analysis is about the case of BUMD asset sales in East Java. In the news on Metro TV, the newsis constructed under the title "Dahlan Iskan is under Arrest" (October 28, 2016).The title utilizes subject phrases and verb phrases,so the focus of the news emphasizes on events or phenomena that befell the subject, namely Dahlan Iskan. The title of the news clearly shows that the core of the news is concerned with the detention of Dahlan Iskan who was set as a suspect in the case of asset sales of BUMDin East Java. This is summarized in the lead on the news as follows.

(5) Tonight Dahlan Iskan completed the investigation as a witness and had been named as a suspect in the case of alleged corruption release of PT Panca Wira Usaha. It is believed that Dahlan Iskan participated in the release of BUMD asset he once led.
(Dahlan Iskan Detained, Metro TV, October 28,2016 )

In the news, the main idea can be found at the beginning of the news in the form of a lead regarding the determination of Dahlan Iskan as a suspect. After the placement of leads, the next sentence in the form of opinion from journalists who believe that Dahlan Iskan participated in the release of an asset from BUMD of East Java. The opinionis then reinforced by the coverage of direct interviews in the field between reporters and the head section of investigation from the Attorney General's Office in East Java, Dandeni Herdiana. The direct interviews were used by the media to convince the public that Dahlan Iskan is guilty. At the end of the news, the reporter informed Dahlan Iskan's inspection plan as a suspect.

Viewed schematically, the above story illustrates the existence of a spin to public opinion that Dahlan Iskan is guilty and worthy of being named as a suspect. This is because,in the news, reporters show more explanatory sentences explaining the evidence of Dahlan's mistakes.

In the same case, the NET reporter constructed the news about the sale of the BUMD's assets under the title "Dahlan Iskan Defined as Suspect" on October 28, 2016. The news begins with a lead presentation on the determination of Dahlan Iskan.

(6) Twelve hours in Attorney General's Office of East Java, former Minister of State-Owned Enterprises, Dahlan Iskan was finally appointed as a suspect in the East Java case by BUMD PT Panca Wira Usaha. (Dahlan Iskan Defined as Suspect, NET, October 28, 2016)

In the above news break, reporters put the main idea at the beginning of the news in the first sentence, namely the determination of suspect status on Dahlan Iskan. On the next sentence, the reporter gave an opinion of alleged mistake Dahlan Iskan on the sale of assets under NJOP. Regarding the determination of Dahlan Iskan, the journalist inserted an excerpt from Dandeni Herdiana's commentary on Dahlan Iskan's investigation which ended as a suspect. After excerpts from Dandeni Herdiana, the journalist also inserted a comparative commentary from Dahlan Iskan regarding his 
opinion that he was never corrupt. After a series of contradictory speeches from both figures, the journalist chose to close the news with Dahlan's activities and review again on the determination of the previous suspect, Vishnu Wardhana.

Viewed schematically, the above news shows the use of argumentation news patterns. Thisis seen with the pattern of pros and cons among the figures' speeches concerned with the cases discussed. After the presentation of leads, journalists chose to insert footage of Dandeni Herdiana's remarks on the determination of Dahlan Iskan as a suspect. However, in the next paragraph, the journalist precisely inserted Dahlan Iskan's contradictory response to his determination as a suspect. In the construction of the news, it showed that journalists simply informed the public and allowed the public to conclude its owninterpretation.

\section{Conclusion}

At the level of the superstructure in the construction of news coverage on Indonesia national private television, a different schematic structure was found. According to van Dijk, schematic importance is a journalist's strategy to support a particular topic to be conveyed by arranging parts in a particular order. Schematic emphasizes the precedence and the parts which can then be put as a strategy to hide important information. The hiding effort is done by placing at the end to make it appear less prominent.

\section{References}

Asher, R.E dan J.M.Y Simpson (Eds). 1994. The Encyclopedia of Language and Linguistics, Volume 2. Oxford: Pergamon Press.

Brown, Gillian dan George Yule. 1996. Discourse Analysis. Cambridge: Cambridge University Press.

Darma, Yoce Aliah. 2009. Analisis Wacana Kritis. Bandung : Yrama Widya.

Dijk, Teun A. van. 1980. Discourse Analysis in Society. London: Academic Press Inc.

Dijk, Teun A.van. 1988a. Newa as Discourse.

New Jersey: Lawrence Erlbaum

Associates Publishers.
Dijk, Teun A.van. 1988b. Macrostructures, An Interdisciplinary Study of Global Structures in Discourse, Interaction, and Cognition. New Jersey: Lawrence Erlbaum Associates Publishers.

Fairclough, Norman. 1995. Critical Discourse Analysis, The Critical Study of Language. New York: Longman.

Fairclough, N dan Ruth Wodak. 1997. "Critical Discourse Analysis: An Overview" dalam Teun van Dijk (ed). Discourse and Interaction. London : Sage Publications, 67-97.

http://www.dw.com/id/indeks-korupsiperingkat-indonesia-membaik-tapimasih-buruk/a-18107694. Diunduh tanggal 27 Mei 2016.

Jorgensen, Marianne W. dan Louise J. Phillips. 2007. Analisis Wacana, Teori dan Metode. Yogyakarta : Pustaka Pelajar.

Leech. Geoffrey. 1997. Prinsip-prinsip Pragmatik. Terj. M.D.D Oka. Jakarta : Universitas Indonesia.

Mardikantoro, Hari Bakti. 2014. "Analisis Wacana Kritis pada Tajuk (Anti) Korupsi Di Surat Kabar Berbahasa Indonesia”. Jurnal Litera, Vol. 13, No. 2, Oktober 2014, hal. 215-225.

Renkema, J. 2004. Introduction to Discourse Studies. Philadelphia : John Benjamin Publishing Company.

Ridwan, Taufik. 2013. Survei: 152.346 Berita Korupsi Selama 2013. http://www.antaranews.com. (diunduh 29 November 2016).

Subagyo, Paulus Ari. 2010. "Pragmatik Kritis: Paduan Pragmatik dengan Analisis Wacana Kritis" dalam Jurnal Linguistik Indonesia, Tahun ke-28, Nomor 2, Agustus 2010, hal. 177-187.

Sudaryanto. 2015. Metode dan Aneka Teknik Analisis Bahasa, Pengantar Penelitian Wahana Kebudayaan secara Linguistis. Yogyakarta : Sanata Dharma University Press. 